
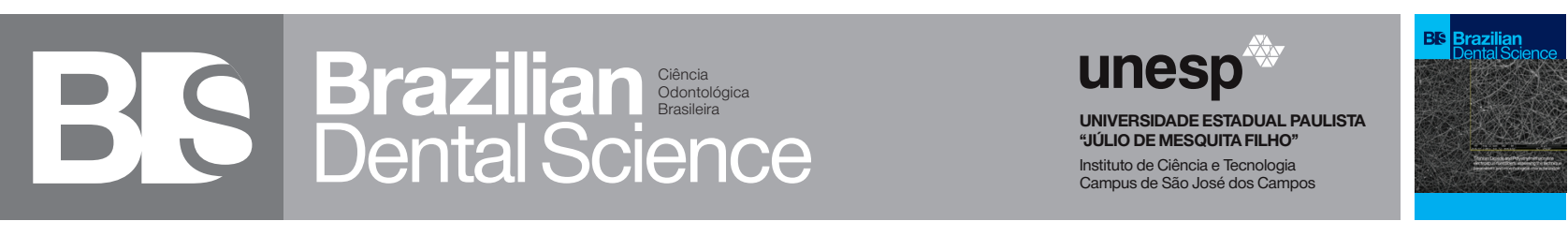

\title{
Antimicrobial effect of methylene blue formulations with oxygen carrier at different pHs: preliminary study
}

Efeito antimicrobiano de formulações de azul de metileno com carreador de oxigênio em diferentes pHs: um estudo preliminar.

Jessica Klöckner KNORST ${ }^{1}$, Gabriela Scarton BARRIQUELLO ${ }^{2}$, Marcos Antonio VILLETTI ${ }^{3}$, Roberto Christ Vianna SANTOS ${ }^{4}$, Karla Zanini KANTORSKI ${ }^{5}$

1 - Graduate Program in Oral Science - Pediatric Dentistry Unit - School of Dentistry - Federal University of Santa Maria - Santa Maria RS - Brazil.

2 - Graduate Program in Oral Science - School of Dentistry - Federal University of Santa Maria - Santa Maria - RS - Brazil.

3 - Graduate Program in Chemistry - Chemical-Physical Unit - Federal University of Santa Maria - Santa Maria - RS - Brazil.

4 - Graduate Program in Pharmaceuticals Science - Federal University of Santa Maria - Santa Maria - RS - Brazil.

5 - Graduate Program in Oral Science - Periodontology Unit - Stomatology Department - School of Dentistry - Federal University of Santa Maria - Santa Maria - RS - Brazil.

\section{ABSTRACT}

Objective: Evaluate methylene blue (MB) formulations containing oxygen carrier at different pHs in antimicrobial photodynamic therapy (aPDT). Material and Methods: Biofilms of Pseudomonas aeruginosa PA01 formed over acrylics specimens during five days were treated with aPDT using different formulations: $\mathrm{MB} / \mathrm{pH}$ 7.4; $\mathrm{MB} / \mathrm{pH}$ 5.6; $\mathrm{MB} /$ carrier $\mathrm{pH}$ 7.4; $\mathrm{MB} /$ carrier $\mathrm{pH}$ 5.6. Biofilms not exposed to treatment were used as a control. Blind examiner for the experimental groups performed the counting of colonies per $\mathrm{ml}$ suspension $(\mathrm{CFU} / \mathrm{ml})$. Two-way ANOVA was used to determine the effect of factors solvent (carrier vs water) and $\mathrm{pH}$ (7.4 vs 5.6). One-way ANOVA and post-hoc Tukey's test was used to evaluate differences among the five groups (control; MB/carrier pH 7.4; $\mathrm{MB} \mathrm{pH} \mathrm{7.4;} \mathrm{MB/carrier}$ $\mathrm{pH}$ 5.6; MB pH 5.6). The Statistics 8.0 software was used $(\mathrm{P}<0.05)$. Results: All of photodynamic therapy groups showed significant reduction in $P$. aeruginosa compared to the control group. The solvent factor was not significant $(\mathrm{P}=0.18)$, while the $\mathrm{pH}$ factor presented statistical significance $(\mathrm{P}=0.01)$. When the carrier was used, $\mathrm{MB}$ formulation at $\mathrm{pH} 7.4$ presented a statistically greater reduction of $P$ aeruginosa than the formulation with $\mathrm{pH}$ 5.6. Conclusion: The PDT using methylene blue formulations with oxygen carrier demonstrated potential for the treatment of localized infections by $P$. aeruginosa. MB formulations with oxygen carrier and $\mathrm{pH} 7.4$ resulted in higher antimicrobial effect and should be considered for future studies with multispecies biofilms.

\section{KEYWORDS}

Antimicrobial photodynamic therapy; biofilm; laser; Pseudomonas aeruginosa.

\section{RESUIMO}

Objetivo: Avaliar formulações de azul de metileno (AM) contendo carreador de oxigênio a diferentes pHs na terapia fotodinâmica antimicrobiana (TFDa). Material e Métodos: Biofilmes de Pseudomonas aeruginosa PA01 formados sobre espécimes acrílicos durante cinco dias foram tratados com TFDa utilizando diferentes formulações: AM / pH 7,4; AM / pH 5,6; AM / carreadir $\mathrm{pH} 7,4 ; \mathrm{AM} /$ carreador $\mathrm{pH}$ 5,6. Biofilmes não expostos ao tratamento foram utilizados como controle. Um examinador cego aos grupos experimentais realizou a contagem de colônias por ml de suspensão (UFC / ml). $\mathrm{O}$ teste Anova dois fatores foi utilizado para determinar o efeito dos fatores solvente (carreador vs água) e $\mathrm{pH}$ $(7,4$ vs 5,6$)$. Anova um fator e teste post-hoc de Tukey foram utilizados para avaliar as diferenças entre os cinco grupos (controle; AM / carreador $\mathrm{pH} 7,4$; $\mathrm{AM} \mathrm{pH} \mathrm{7,4;} \mathrm{AM}$ / carreador pH 5,6; AM pH 5,6). O software Statistics 8.0 foi utilizado $(\mathrm{P}<0,05)$. Resultados: Todos os grupos da terapia fotodinâmica mostraram uma redução significativa na $P$. aeruginosa em comparação ao grupo controle. $\mathrm{O}$ fator solvente não foi significante $(P=0,18)$, enquanto o fator $\mathrm{pH}$ apresentou significância estatística $(\mathrm{P}=0,01)$. Quando o carreador foi utilizado, a formulação AM a pH 7,4 apresentou uma redução estatisticamente maior de $P$. aeruginosa do que a formulação com pH 5,6. Conclusão: A TFDa utilizando formulações de AM com carreador de oxigênio mostrou potencial para o tratamento de infecções localizadas por $P$. aeruginosa. As formulações de AM com carreador de oxigênio e pH 7,4 resultaram em maior efeito antimicrobiano e devem ser consideradas para futuros estudos com biofilmes multiespécie.

\section{PALAVRAS-CHAVE}

Terapia fotodinâmica antimicrobiana; Biofilme; Laser; Pseudomonas aeruginosa. 


\section{INTRODUCTION}

A ntimicrobial photodynamic therapy (aPDT) has been proposed as an adjuvant to antibiotic treatment [1] with low probability of causing bacterial resistance [2], being effective against strains resistant to antibiotics [3]. Attempts to optimize the effect of aPDT such as news photosensitizer (Ps), changes in the solvent of formulations [4,5], addition of oxygen carriers [4], nanoplatforms for the application of Ps [6,7], inhibitors of efflux pump $[8,9]$, antibodies conjugated to Ps [10], have been investigated.

The singlet oxygen, due to its strong oxidative activity [11], has been considered the main responsible for the antimicrobial effect of aPDT [4]. In oral biofilms, especially in those located in subgingival environments, there are areas with different oxygen gradients and under anaerobiosis conditions. Therefore, the combination of Ps and light may not be sufficient for the effective eradication of biofilm [12]. Strategies to improve oxygenation in systems subject to photodynamic therapy have been studied [13]. The use of oxygen carriers could increase the availability of oxygen and facilitate the propagation of light during the irradiation, increasing the photochemical oxidation potential, facilitating the disruption of the biofilm matrix and the eradication of bacteria [12,14]. Perfluorocarbons (PFCs), such as perfluorideecalene, is a petroleum derivative synthesized by the substitution of hydrogen atoms for fluorine atoms in hydrocarbon molecules. The solubility of oxygen in PFCs is 10 to 20 times greater than in water, and their characteristics significantly increase the rate of oxygen transfer from the gas phase to microorganisms $[15,16]$. Kamuhabawa et al., in 2006, observed that the addition of perfluorecarene resulted in enhanced effect of photodynamic therapy with hypericin inducing increased apoptosis of tumor cell carcinoma [17].

The pH-dependent behavior of some Ps has been investigated $[18,19]$. The amount of hydroxyl radicals $(\mathrm{OH})$ present in the environment increases according to the $\mathrm{pH}$ solution. The more basic the $\mathrm{pH}$, more hydroxyl radicals $(\mathrm{OH})$. These radicals react with biomolecules or combine with each other and form hydrogen peroxide, which has cytotoxic effects [20]. Studies have shown that $\mathrm{pH}$ can alter the fluorescence spectrum and chlorine absorbance. It may still alter molecular characteristics and the interaction of Ps with tumor cells during photodynamic therapy [2123]. There is evidence that the production of singlet oxygen can be potentiated according to the $\mathrm{pH}$ [24]. Photosensitive phthalocyanines present greater potential to produce reactive oxygen species (ROS) and singlet oxygen in acid environment [19].

There is no evidence demonstrating the effect of $\mathrm{pH}$ or the addition of oxygen carrier on the antimicrobial effect of photodynamic therapy when methylene blue (MB) is used as Ps. Moreover, we used Pseudomonas aeruginosa biofilm. In biofilms, P. aeruginosa resistance to antibiotics can be 10 to 1,000 times greater than that in planktonic culture [25] Therefore, the P. aeruginosa biofilm consists in an important model for evaluating the antimicrobial effect of the photodynamic therapy.

The objectives of this pilot study were: (1) to compare the antimicrobial effect of aPDT among formulations containing $\mathrm{MB}$ in aqueous solution with an experimental formulation containing $\mathrm{MB}$ and an oxygen carrier substance; and (2) to evaluate the $\mathrm{pH}$ effect of MB formulations on antimicrobial effect on $P$. aeruginosa biofilms. Our hypothesis considered that the formulation containing the oxygen carrier would result in the highest antimicrobial effect.

\section{MATERIAL AND METHODS}

The Ps used was methylene blue (Sigma Aldrich ${ }^{\circledR}$, São Paulo, SP, Brazil). Solutions were prepared using ultra-pure water (Milli-Q). To prepare the buffered solutions the following materials were used: Tris (hydroxymethyl) aminomethane (Sigma Aldrich ${ }^{\circledR}$ ) and hydrochloric acid (Vetec $\AA$, Rio de Janeiro, RJ, 
Brazil) for pH 7.4; and acetic acid $\left(\operatorname{Vetec}^{\circledR}\right)$ and sodium acetate (Proquímios ${ }^{\circledR}$, Rio de Janeiro, $\mathrm{RJ}$, Brazil) for $\mathrm{pH}$ 5.6. Perfluordecalene (Acros Organics $^{\circledR}$, New Jersey, USA) was used as an oxygen carrier, and triton-X100 (Sigma Aldrich ${ }^{\circledR}$ São Paulo, SP, Brazil) was used as a surfactant in the preparation of the emulsions.

The $\mathrm{pH}$ of the solutions was adjusted using the DM-20 pH meter (Digimed ${ }^{\circledR}$, São Paulo, SP, Brazil), and solutions of hydrochloric acid and sodium hydroxide $\left(\operatorname{Vetec}^{\circledR}\right)$ were used to achieve the expected $\mathrm{pH}$.

The light source used was an IndiumGallium-Aluminum-Phosphorus laser (InGaAlP, Thera Lase - DMC, São Carlos, SP, Brazil) with a wavelength of $660 \mathrm{~nm}$, fiber tip diameter of $0.02827 \mathrm{~cm}^{2}$, and continuous emission mode. The formulations tested are shown in Table 1.

Table 1 - Formulations of methylene blue (MB) at different pHs submitted to the irradiation.

\begin{tabular}{|c|c|}
\hline Formulations & Formultion compositions \\
\hline MB pH 7.4 & MB (0.01\%) diluted in buffer (Tris-HCl) \\
\hline MB/carrier* pH 7.4 & $\begin{array}{l}\text { MB (0.01\%) diluted in a perfluorodecalene: buffer } \\
\text { (Tris-HCI): triton-X100 ratio 60:35:5, }\end{array}$ \\
\hline MB pH 5.6 & $\begin{array}{l}\text { MB (0.01\%) diluted in buffer (sodium acetate/ } \\
\text { acetic acid); }\end{array}$ \\
\hline MB/carrier* pH 5.6 & $\begin{array}{c}\mathrm{MB}(0.01 \%) \text { diluted in a perfluorecarene emul- } \\
\text { sion: buffer (sodium acetate/ acetic acid): triton } \\
\text {-X100 60:35:5 }\end{array}$ \\
\hline
\end{tabular}

\section{Antimicrobial effect of MB in different biofilm formulations in vitro}

Biofilms of standard laboratory strains of P. aeruginosa PA01 (gram-negative) were formed in vitro on acrylic disks with an $8 \mathrm{~mm}$ diameter. A standardized suspension containing $10^{7}$ cells $/ \mathrm{ml}$ of microorganism was obtained with a spectrophotometer (Instrutherm, UV1000A, São Paulo, SP, Brazil). Optical density parameter of $1\left(\mathrm{OD}_{600 \mathrm{~nm}}\right)$ was used.

Sterile acrylic specimens (measuring $8 \mathrm{~mm}$ in diameter, $1 \mathrm{~mm}$ in height) were placed in a 24-well plate (Costar Corning,
New York,NY, USA). Two milliliters (2 mL) of Brain Heart Infusion broth (BHI, Himedia Laboratories PVT. Ltd., Mumbai, India) plus $5 \%$ sucrose was pipetted into each well. BHIimmersed specimens were inoculated with 100 $\mu \mathrm{L}$ of standardized microbial suspension $\left(10^{7}\right.$ cells $/ \mathrm{ml}$ ) and incubated in an orbital shaker (Novatecnica, Model NT712, Piracicaba, SP, Brazil) under $75 \mathrm{rpm}$ and $37^{\circ} \mathrm{C}$ for 5 days. The broth was refreshed every 24 hours. After the incubation period, the specimens were washed with $2 \mathrm{ml}$ of buffered saline solution with phosphate (PBS), to remove the cells.

\section{Photodynamic Inactivation of Biofilms}

After washing with saline solution, the specimens were transferred to new 24-well plates and immersed in $1 \mathrm{ml}$ Ps $(250 \mu \mathrm{M})$ in the different formulations. The Ps solution was maintained in contact with the biofilm for $5 \mathrm{~min}$ without light application (incubation period) and afterwards, the biofilms were irradiated with low power laser with $660 \mathrm{~nm}$ wavelength, in continuous emission mode, usable power of $30 \mathrm{~mW}$, energy of $20 \mathrm{~J}$ and energy density of $40 \mathrm{~J} / \mathrm{cm}^{2}$, for $10 \mathrm{~min}$.

Afterwards, each specimen containing biofilm was placed in falcon tube containing $10 \mathrm{ml}$ of saline solution and placed under vortexing (VELP Scientifica, $12 \mathrm{dc}$ ) with power of $15 \mathrm{~W}$ for 30s. Decimal dilutions were performed from the homogenized solution $\left(10^{-1}\right)$. Onehundred microliters $(100 \mu \mathrm{l})$ aliquots of each dilution were seeded in Petri dishes containing MacConkey agar (Himedia Laboratories PVT, Ltd., Mumbai, India).

Plates were incubated at $37^{\circ} \mathrm{C}$ for $48 \mathrm{~h}$. After that period, a blind examiner for the experimental groups counted the colonies formed on the plates and the colony forming unit (CFU) calculation per $\mathrm{mL}$ of suspension $(\mathrm{CFU} / \mathrm{ml})$.

Five specimens per formulation were used. The experiment was carried out in triplicate. The biofilm formed on the specimens and not exposed to treatment was used as control. 


\section{Statistical analysis}

The data CFU/ml (Log) were presented on average, standard deviation and 95\% confidence interval. Two-way ANOVA was used to evaluate the effect of $\mathrm{pH}$ factor (7.4 versus 5.6) and solvent factor (aqueous versus carrier solution). One-way ANOVA and post hoc Tukey's were used to assess the differences among the five groups (control; $\mathrm{MB} /$ carrier 7.4; $\mathrm{MB} 7.4$; $\mathrm{MB} /$ carrier 5.6; MB 5.6). Significance level of $5 \%$ was used for all evaluations. Statistics 8.0 (StatSoft. Inc., Tulsa, OK, United States) program was used for all analyzes.

\section{RESULTS}

The solvent factor (water versus carrier) was not statistically significant $(\mathrm{P}=0.18)$, while the $\mathrm{pH}$ factor (7.4 versus 5.6) presented statistical significance $(\mathrm{P}=0.01)$. The interaction of factors was not significant $(\mathrm{P}=0.62)$.

The data CFU/ml (Log) in the experimental groups are presented in Table 2. All groups of aPDT presented statistically significant reduction of $P$. aeruginosa in comparison to the absence of treatment. No difference was found between groups with the same $\mathrm{pH}$. When water was used as solvent, no difference was observed between $\mathrm{pH} 5.6$ and 7.4. When the oxygen carrier was used, the MB formulation at $\mathrm{pH} 7.4$ exhibited statistically significant reduction of $P$ aeruginosa compared to the formulation at $\mathrm{pH}$ 5.6.

Table 2 - Mean CFU/mL \pm standard deviation for the biofilms of $P$. aeruginosa in the control group (no treatment) and in the other antimicrobial photodynamic therapy groups.

\begin{tabular}{|ccc|}
\hline & \multicolumn{2}{c}{ Experimental groups } \\
\hline & $\mathrm{pH} 7.4$ & $\mathrm{pH} 5.6$ \\
\hline $\begin{array}{c}\text { Control/no } \\
\text { treatment }\end{array}$ & \multicolumn{2}{c|}{$6.88 \pm 0.14(6.71-7.06) \mathrm{a}$} \\
\hline $\mathrm{MB} /$ carrier & $3.54 \pm 0.78(2.56-4.52) \mathrm{b}$ & $4.86 \pm 0.50(4.22-5.49) \mathrm{C}$ \\
\hline $\mathrm{MB} /$ water & $4.12 \pm 0.70(3.24-5.00) \mathrm{bc}$ & $5.13 \pm 0.68(4.28-5.97) \mathrm{c}$ \\
\hline
\end{tabular}

Anova one-way, post hoc Tukey

Different letters: represent statistically significant difference among the groups $(P<0.05)$.

\section{DISCUSSION}

The results demonstrated that the inclusion of the oxygen carrier in the $\mathrm{MB}$ formulation did not increase antimicrobial effect in relation to the commonly used formulation containing $\mathrm{MB}$ in aqueous solution, which disproved our initial hypothesis. We observed that most basic $\mathrm{pH}$ had statistically significant effect on the antimicrobial photodynamic effect. Formulations with $\mathrm{pH} 7.4$ had lower mean values of $\mathrm{CFU} / \mathrm{ml}$ than those with $\mathrm{pH}$ 5.6. Furthermore, the formulation containing $\mathrm{MB} /$ carrier at $\mathrm{pH} 7.4$ showed statistically higher antimicrobial effect than formulations with $\mathrm{pH}$ 5.6.

The most basic $\mathrm{pH}$ (7.4) favored the antimicrobial effect. The mechanism(s) that explain this effect need to be elucidated. Previous publications indicate the effect of $\mathrm{pH}$ seems to vary according to the characteristics of the Ps used $[18,19]$. However, there is evidence that for some Ps the basic $\mathrm{pH}$ seems to provide greater amount of hydroxyl radicals $(\mathrm{OH})$ in the environment. These radicals react with biomolecules or combine with each other and form hydrogen peroxide, which has cytotoxic effects $[18,19]$.

Theoretical basis for the use of an oxygen carrier would be the possibility of increasing the oxygen supply in the biofilm favoring the production of singlet oxygen via photodynamic activation and, consequently, increasing the antimicrobial effect [12,26]. However, our experiments didn't observe this effect. The use of the carrier may not necessarily have driven more oxygen to the biofilm. Thus, further experiments adding oxygen-carrying substances together with the carrier can be performed.

The aPDT used in the present study, regardless of the formulation or $\mathrm{pH}$ used, were effective, since they presented statistically significant reduction in viability $P$. aeruginosa in all groups in comparison to the control group (no treatment). These results confirm previous studies demonstrating that aPDT are effective in several species of microorganisms $[27,28]$. The concentration of $\mathrm{MB}$ used in the present 
study was based on a previous study that demonstrated that formulations of $0.01 \% \mathrm{MB}$ resulted in significantly higher production of singlet oxygen when compared to concentrations of $0.001 \%, 0.0001 \%$ and $0.1 \%$ [29]. The choice of biofilms of $P$. aeruginosa was guided by the following factors: (I) being a Gram-negative bacteria, which are naturally more resistant to aPDT when compared to Gram-positive ones [30,31]; due to the outer membrane presenting lipopolysaccharides (LPS) and pore channels that act as a barrier to the photosensitizer penetration; (II) due to its high degree of genomic flexibility, expressing several phenotypes, thus recognized by its intrinsic resistance to antibiotics [32,33], which may be 10 to 1000 times higher than in planktonic culture [34]; (III) by previous evidence demonstrating the need for a higher dose of energy and higher concentration of Ps to alter the viability of $P$. aeruginosa when compared to other microorganisms [30].

In the present study only used untreated biofilm as a control group. The literature has pointed out that MB without photoactivation, or laser without $\mathrm{MB}$, has little or no antimicrobial effect [35], justifying the absence of these comparison groups. However, as limitations of this study, we pointed out that biofilm exposure to buffer solutions and to the oxygen carrier could have been performed to verify if these substances have any antimicrobial effect. Another limited aspect is the reduced number of samples used (n $=5$ ), which compromises the power of the study to identify statistical significance in the tests. However, this is a preliminary study. Moreover, more than statistical significance, we could consider that a difference of approximately $2 \mathrm{log}$ $\mathrm{CFU} / \mathrm{ml}$ among treatments could be considered microbiologically important in reducing the viability of P. aeruginosa in biofilms [36]. In addition, our findings are in agreement with other studies that used this type of $\mathrm{pH}$ [37-39].

The magnitude of the microbial reduction observed in the formulation containing $\mathrm{MB} /$ oxygen carrier at $\mathrm{pH} 7.4$ was similar to that observed with antibiotics on $P$ aeruginosa biofilms [40,41]. This demonstrates that
aPDT with these formulations may be a viable alternative and with no risk of adverse reactions or development of microbial resistance.

\section{CONCLUSION}

The present study demonstrated that formulations containing $\mathrm{MB}$ and oxygen carrier with $\mathrm{pH} 7.4$ resulted in higher antimicrobial effect when compared to $\mathrm{pH} 5.6$ during aPDT on $P$ aeruginosa biofilms. Thus, aPDT with such formulation seems to be promising to act as a supporting agent in the treatment of localized infections. Our preliminary results need be confirmed in models involving multi-species biofilms.

\section{REFERENCES}

1. Yin R, Hamblin MR. Antimicrobial Photosensitizers: Drug Discovery Under the Spotlight. Curr Med Chem. 2015;22(18):2159-85.

2. Giuliani F, Martinelli M, Cocchi A, Arbia D, Fantetti L, Roncucci G. In vitro resistance selection studies of RLP068/ Cl, a new Zn(II) phthalocyanine suitable for antimicrobial photodynamic therapy. Antimicrob Agents Chemother. 2010 Feb;54(2):637-42. doi:10.1128/AAC.00603-09.

3. Maisch T.A new strategy to destroy antibiotic resistant microorganisms: antimicrobial photodynamic treatment. Mini Rev Med Chem. 2009 Jul;9(8):974-83.

4. George S, Kishen A. Photophysical, photochemical, and photobiological characterization of methylene blue formulations for light-activated root canal disinfection. J Biomed Opt. 2007 May-Jun;12(3):034029.

5. Prochnow EP, Martins MR, Campagnolo CB, Vianna RC, Villetti MA, Kantorski KZ. Antimicrobial photodynamic photosensitizers in formulations with etanol on Pseudomona aeruginosabiofilms. Photodiagnosis Photodyn Ther. 2016 Mar;13:291-296. doi: 10.1016/j.pdpdt.2015.08.008.

6. Klepac-Ceraj V, Patel N, Song X, Holewa C, Patel C, Kent R, etal. Photodynamic effects of methylene blue-loaded polymeric nanoparticles on dental plaque bacteria. Lasers Surg Med. 2011 Sep;43(7):600-6. doi: 10.1002/ Ism.21069.

7. Sherestha A, Kishen A. The Effect of Tissue Inhibitors on the Antibacterial Activity of Chitosan Nanoparticles and Photodynamic Therapy. JEndod. 2012 Sep;38(9):1275-8. doi: 10.1016/j.joen.2012.05.006. Epub 2012 Jul 7.

8. Tegos GP, Masago K, Aziz F, Higginbotham A, StermitzFR, Hamblin MR. Inhibitors of bacterial multidrug efflux pumps potentiate antimicrobial photoinactivation. Antimicrob Agents Chemother. 2008 Sep;52(9):3202-9. doi: 10.1128/AAC.00006-08. Epub 2008 May 12.

9. Kishen A, Upadya M, Tegos GP, Hamblin MR. Efflux pump inhibitor potentiates antimicrobial photodynamic inactivation of Enterococcus faecalis biofilm. Photochem Photobiol. 2010 Nov-Dec;86(6):1343-9. doi: 10.1111/.j.17511097.2010.00792.x. Epub2010 Sep 22. 
10. Embleton ML, Nair SP,Cookson BD, Wilson M. Antibody-directed photodynamic therapy of methicillin resistant Staphylococcus aureus. Microb Drug Resist. 2004 Summer;10(2):92-7.

11. Harris F, Chatfield LK, Phoenix DA. Phenothiazinium Based Photosensitisers - Photodynamic Agents with a Multiplicity of Cellular Targets and Clinical Applications. Curr Drug Targets. 2005 Aug;6(5):615-27.

12. Saji G, Kishel A. Augmenting the Antibiofilm Efficacy of Advanced Noninvasive Light Activated Disinfection with Emulsified Oxidizer and Oxygen Carrier. J Endod. 2008 Sep;34(9):1119-23. doi:10.1016/j. joen.2008.06.019.

13. Huygens A, Kamuhabwa AR, Van Laethem A, Roskams T, Van Cleynenbreugel B, Van Poppel $H$, et al. Enhancing the photodynamic effect of hypericin in tumour spheroids by fractionated light delivery in combination with hyperoxygenation. Int J Oncol. 2005 Jun;26(6):1691-7.

14. Amaral PF, Rocha-Leão MH, Marrucho I, Coutinho JA, Coelho MA. Improving lipase production useing a perfluorcarbon as oxygen carrier. JChem Technol Biotechnol. 2006;81:1368-74.

15. Riess JG, Le Blanc M. Solubility and transport phenomena in perfluorchemicals relevant to blood substitution and other biomedical applications. Pure Appl Chem. 1982;54(12):2383-406.

16. Elibol M, Mavituna F.Effect of perfluordecalin as an oxygen carrier on actinorhodin production by Streptomyces coelicolor A3. Appl Microbiol Biotechnol. 1995 May-Jun;43(2):206-10.

17. Kamuhabwa AR, Huygens A, Roskams T, De Witte PA. Enhancing the photodynamic effect of hypericin in human bladder transitional cell carcinoma spheroids by the use of the oxygen carrier, perfluorodecalin. Int $J$ Oncol. 2006 Mar;28(3):775-80.

18. Li W, Gandra N, Ellis ED, Courtney S, Li S, Butler E, Gao R. pH-responsive, Ti02-attached porphyrin for singlet oxygen production in aqueous solution. ACS Appl Mater Interfaces. 2009 Aug;1(8):1778-84. doi: 101021/am9003039.

19. Jiang XJ. et al. Phthalocyanine-polyamine conjugates as pH-controlled photosensitizers for photodynamic therapy. Chemistry.2010 Apr 26;16(16):4777-83. doi:10.1002/chem.200903580.

20. Wainwright M, Giddens RM. Phenothiazinum photosensitisers: choices in synthesis and application. Dyes Pigm. 2003;57(3):245-57.

21. Čunderlíková, Beata, et al. pH-Dependent modification of lipophilicity of porphyrin-type photosensitizers. J Photochem Photobiol B. 2004;79(3)24247.

22. Cunderlíková B, Gangeskar L, Moan J. Acid-base properties of chlorin e6: relation to cellular uptake. JPhotochem Photobiol B. 1999 NovDec;53(1-3):81-90

23. Cunderlíková B, Bjørklund EG, Pettersen E0, Moan J. pH-dependent spectral properties of HpIX, TPPS2a, mTHPP and mTHPC. Photochem Photobiol. 2001 Aug;74(2):246-52.

24. Friberg EG, Cunderlíková B, Pettersen E0, Moan J. pH effects on the cellular uptake of four photosensitizing drugs evaluated for use in photodynamic therapy of cancer. Cancer Lett. 2003 May;195(1):73-80.
25. Nickel JC, Ruseska I, Wright JB and Costerton JW. Tobramycin resistance of Pseudomonas aeruginosa cells growing as a biofilm on urinary catheter material. Antimicrob Agents Chemother. 1985 Apr;27(4):619-24.

26. McDonnell SO, O'Shea DF. Near-infrared sensing properties of dimethlyamino-substituted BF2-azadipyrromethenes. Org Lett. 2006 Aug;8(16):3493-6.

27. George S, Kishen A. Augmenting the antibiofilm efficacy of advanced noninvasive light activated disinfection with emulsified oxidizer and oxygen carrier. J Endod. 2008 Sep;34(9):1119-23.

28. Peloi LS, Soares RR, Biondo CE, Souza VR, Hioka N, Kimura E. Photodynamic effect of light-emitting diode light on cell growth inhibition induced by methylene blue. JBiosci. 2008 Jun;33(2):231-7.

29. Vilela SF, Junqueira JC, Barbosa J0, Majewski M, Munin E, Jorge A0. Photodynamic inactivation of Staphylococcus aureus and Escherichia col biofilms by malachite green and phenothiazine dyes: an in vitro study. Arch Oral Biol. 2012 Jun;57(6):704-10. doi: 10.1016/j.archoralbio.2011.12.002. Epub 2011 Dec 28.

30. Komine C, Tsujimoto Y. A small amount of singlet oxygen generated via excited methylene blue by photodynamic therapy induces the sterilization of Enterococcus faecalis. J Endod. 2013 Mar;39(3):411-4. doi: 10.1016/j. joen.2012.11.051. Epub 2013 Jan 23.

31. Usacheva MN, Teichert MC, Biel MA. Comparison of the methylene blue and toluidine blue photobactericidal efficacy against gram-positive and gramnegative microorganisms. Lasers Surg Med. 2001;29(2):165-73.

32. Soukos NS, Goodson JM. Photodynamic therapy in the control of oral biofilms. Periodontol 2000.2011Feb;55(1):143-66. doi: 10.1111/j.16000757.2010.00346.x

33. Hancock RE, Speert DP. Antibiotic resistance in Pseudomonas aeruginosa: mechanisms and impact on treatment. Drug Resist Updat. 2000 Aug;3(4):247-255

34. Sharma G, Rao S, Bansal A, Dang S, Gupta S, Gabrani R. Pseudomonas aeruginosa biofilm: Potential therapeutic targets. Biologicals. 2014 Jan;42(1):1-7. doi:101016/j.biologicals.2013.11.001. Epub2013 Dec 3.

35. Meisel P,Kocher T.Photodynamic therapy for periodontal diseases: state of the art. J Photochem Photobiol B. 2005 May 13;79(2):159-70.

36. Rovaldi CR, Pievsky NA. Sole PM. Photoactive Porphyrin Derivative with Broad-Spectrum Activity against Oral Pathogens In Vitro. Antimicrob Agents Chemother.2000 Dec;44(12):3364-7.

37. Silva ZS Jr, Huang YY, de Freitas LF, França CM, Botta SB, Ana PA, et al. Papain gel containing methylene blue for simultaneous caries removal and antimicrobial photoinactivation against Streptococcus mutans biofilms. Sci Rep. 2016 Sep 19;6:33270. doi: 10.1038/srep33270.

38. Nemezio MA, de Souza Farias SS, Borsatto MC, Aires CP, Corona SAM. Effect of methylene blue-induced photodynamic therapy on a Streptococcus mutans biofilm model. Photodiagnosis Photodyn Ther. 2017 Dec;20:234-237. doi:10.1016/j.pdpdt.2017.10.025. Epub2017 0ct31.

39. Méndez DAC, GutierrezE, Dionísio EJ, Oliveira TM, Buzalaf MAR, Rios D, et al. Effect of methylene blue-mediated antimicrobial photodynamic therapy on dentin caries microcosms Lasers Med Sci. 2018 Apr;33(3):479-487. doi: 10.1007/s10103-017-2379-3. Epub2017 Nov 8. 
40. Yu Q, Griffin EF, Moreau-Marquis S, Schwartzman JD, Stanton BA, O’Toole GA. In vitro evaluation of tobramycin and aztreonam versus Pseudomonas aeruginosabiofilms on cystic fibrosis-derived human airway epithelial cells. J Antimicrob Chemother. 2012 Nov;67(11):2673-81. doi: 10.1093/jac/dks296. Epub2012 Jul 26.
41. Elkhatib W, Noreddin A. Efficacy of ciprofloxacin-clarithromycin combination against drug-resistant $P$ seudomonas aeruginosamature biofilm sing in vitro experimental model. Microb Drug Resist. 2014 Dec;20(6):575-82. doi: 10.1089/mdr.2014.0024.

\section{Jessica Klöckner Knorst}

(Corresponding address)

Marechal Floriano Peixoto Street 1184, 97015-372, Santa Maria/RS, Brazil.

Date submitted: 2018 Jul 30

Tel.: +55.55.3220.9284. 